\title{
Language and Colour of Skin: A Frantz Fanonian Cultural Study
}

Sujoy Barman ${ }^{+}$

\section{Abstract}

This study is an extraction from the cultural theory of Frantz Fanon, who is regarded as the father of the theory of violence. In the Frantz Fanonian cultural study, discrimination is noticed on the basis of the colour of skin and the exercise of languages and literature, and these are the proposed areas and explained in this article. In the cultural study, for the indigenous background, the black people lead an absurd life in the white cultural society and as well as in the black cultural community in the presence of their white masters. The present study attempts to find out Fanon's ideologies on the roles of languages, literature, and colour to explain the relation between black and white people and the cultural subjectivity and objectivity. It attempts to fill the gap of the neglected areas in the Frantz Fanonian study in the Manichean society. These neglected areas are the roles of language, literature, and skin colour for the cultural discrimination in the postcolonial cultural study. It also finds out the reasons behind abolishing the black culture at the presence of the white culture and recognising the issues for the black cultural revival after its abolishment in newly liberated countries.

Keywords: Race; Cultural Conflict; Hegemony; Negro Culture; Revival of Culture

\footnotetext{
† Independent Scholar, Email: sujoybarman89@gmail.com

(C) 2021 Barman. This is an Open Access article distributed under the terms of the Creative Commons Attribution License (http://creativecommons.org/licenses/by/2.0), which permits unrestricted use, distribution, and reproduction in any medium, provided the original work is properly cited.
} 


\section{Introduction}

In the twenty-first century, Black Lives matter across the globe is a big question as Black Lives regularly face humiliation and are subverted from the mainstream of society. The Black Lives Matter movement became far more intense with the murder of George Floyd on 25 May 2020 by Derek Chauvin, one of the police officers of Minneapolis police (Eligon et al., 2020). One should, however, note that racism is not restricted to the West alone. Indeed, it is a universal phenomenon found across the globe, including India (for details, please read the recent book on racism and discrimination against the people of North East India by Pulla et al.,2020). This study is about the language, literature, and skin colour using the lens of Frantz Fanonian's cultural study, delineating the people of colour and their cultural struggles to survive in contemporary society. Frantz Fanon (1925-1961) is a renounced name in the Black Cultural movement to endure the black lives and black culture. Fanon is the prophet of revolution theorist of race and cultural study, and he is popularly known for his theory of violence. He is acclaimed for the explanation of cultural discrimination based on the colour of skin and the exercise of language in the postcolonial cultural study. The colour of skin and dialects are two significant fields of Frantz Fanon's cultural study. British historian Paul Gilroy in his book The Black Atlantic: Modernity and Double Consciousness (1993), presents double consciousness in the identity of coloured Africans based on the culture that is reflected through language, literature, and skin colour.

He lived only thirty-six years but has left behind a rich, provocative, and inspiring legacy in the cultural and postcolonial theory field. In his short period of living, he experienced cultural discrimination between indigenous and French cultures. He was born in a middle-class coloured family on the island of Martinique in 1925, and during this time, Martinique was a French colony. He had a first-hand experience of the rudeness of French colonialism from his early childhood. The Negroes and other people of colour are eliminated for their colour and dialects from the mainstream of society. Fanon was a grandson of a former slave. His father, Casimir Fanon, was a prosperous Martinique who served as a civil servant and a customs officer. His mother ran a shop, and she was a mulatto woman. Though Fanon belonged to a prosperous family, he had to face cultural discrimination in his homeland and in his master land for his skin colour and dialect. At his early age, influenced by the contemporary race and cultural activist lectures, Aime Cesaire became an ardent disciple of Aime Cesaire. At the age of seventeen, he joined the French army during the Second World War against German Nazism. Biographer Alice Ckerki in Frantz Fanon: A Portait (2006) presents a critical relation between black intellects and black youths for the Second World War. The black intellects prevented the young black people from joining the army because the World War was the white problem, which meant that a white man would kill another white man. Like other young black people, Frantz Fanon enlisted in the French army, fought for the French, and was awarded humiliation from the French people for whom he had come to sacrifice his life. After the Second World War, he enrolled in medical school at the University of Lyons in Paris on scholarship. He became involved with leftist activities in Paris, where he once again faced the problem of his black origin. In 1953 he had joined as the head of the psychiatrist department in Blida- Joinville Hospital in Algeria, and it was a French colony in North Africa, and in the next year (1954), the Algerians revolted against the French colonial government led by the National Liberation Front (FLN). He supported the independent Algerian movement and resigned from his job as a psychiatrist under the French colonial government in Algeria. He edited the journal of the National Liberation Front.

The biographers, especially Alice Cherki and David Macey, have pointed that he gathered the experience of cultural prejudice throughout his life. In his childhood, he noticed the cultural discrimination in Martinique. In Europe, as a 
French soldier during the Second World War, Fanon received White people's prejudice for his blackness, and in Algeria, as a psychiatrist, he became an activist against the French colonial government. The death of Frantz Fanon is a mysterious one, according to some Fanonian scholars. Renate Zahar in Frantz Fanon: Colonialism and Alienation (1974) criticises the administrative difficulties in Washington for the negligence and delay in treatment of Frantz Fanon. He remained without any medical treatment in Washington for a week, and such a complicated administrative system was a significant reason for the death of Frantz Fanon.

Culture is one of the essential areas of study in contemporary theory and criticism. According to history, colonialism started with the persuasion of the financial benefit of the European countries. The colonies were the primary resources of European capitalism as the raw materials, slaves, and indentured labours were affluent in the colonies, which were also the markets of European products. In his A Short History of Colonialism (2011), Wolfgang Reinhard presents a historical narration of colonialism and its financial benefit for Western colonial countries. Besides the financial extortion, colonialism influenced the culture of the colonised people. Culture is described as a method of a particular way of life to a certain group of people in a particular geographical land. Particular ideologies shape cultural life based on anthropology, financial structure, religion, ethnic background, and other living concepts. The Victorian critic Mathew Arnold in his Culture and Anarchy (1869) relates culture with a dignified way of life, and for him, the culture stands for the high qualities in life.

But on the other hand, Raymond Williams considers culture as undefined and a complicated term to explain correctly, and he presents an explanation of culture and its importance in society in his book Culture and Society (1960). Every country has its own culture, and a culture of a colony has lost its indigenous value in the presence of the European colonial culture. The cultural critic Raymond Williams relates the culture with the spiritual, intellectual, and imaginative work. He has used the culture in the intellectual field. The culture is the embodiment of human thought and experience. In the postcolonial cultural study, the scholars focus on the ethnical and anthropological backgrounds, the exercise of dialect, language, literature, and skin colour as their areas of interest. Paul Gilroy in The Black Atlantic Modernity and Double Consciousness (1993) craftily explains preferred areas in the contemporary postcolonial cultural studies, and he presents the complexity of people of colour in the society. The cultural elimination in a colonised society is found according to the power structure of the society. According to the Eurocentric concept, White Man's Burden, the colonial masters think of their culture as superior and master culture, and the indigenous culture as inferior subjective culture, and the indigenous people practice the old backdated wild culture. Cultural superiority creates cultural inferiority. In the colonial extortion system, the culture is soft power domination for the people in colonies. Antonio Gramsci talks about the "cultural hegemony", and the culture is identified as soft power domination in the postcolonial power system. In his Prison Notebooks (1999), Gramsci explains the culture as a weapon to dominate the people, and in the postcolonial study, it is noticed that the white masters dominate their black subject through the implication of culture. The masters create such a cultural atmosphere where the indigenous people find their decayed identity or an absurd existence in the presence of whites. They lead an absurd cultural life. Frantz Fanon, the father of the theory of violence in the postcolonial study also theorises nonviolence in the power implementation in the postcolonial cultural study. He defends the black culture, black race and attempts to bring the reputation of the culture of the coloured people in the white society.

Fanon created a platform for the culture of the coloured people in the international cultural study. He stresses dialects and the colour of skin, and their roles in the cultural humiliation between black and white people. Both colour and language are the two essential parts of any cultural society. The language and literature of 
any ethnic group are the spirits and mediums of cultural expression. They play the roles of Oxygen for any culture. The cultural value of any society is reflected through the exercise of language and literature, and if the language and literature of any particular society are dominated, then the culture of this society is also automatically dominated. In Black Skin, White Masks (1952, 1986), Fanon shows the importance of skin colour for the survival of black people and black culture, and he considers skin colour as one of the major issues for the deprived situation of black culture from the mainstream of the international culture. Here, Frantz Fanon also explains the role of dialect for the subservient position of colonised culture.

Race, colour of skin, language, and literature are interlinked, and they are precious objects in the cultural study. According to the Oxford Dictionary of Critical Theory, race is the biological, physiological, or genetic classification of humans according to distinctive physical appearance features such as skin colour, the shape of face, hair colour, and body morphology. The human is divided into subspecies according to ethnicity, language, and appearance or structure of the body. In the 1730s, Carl Linnaeus, in the introduction of his systematic taxonomy, recognised four main human subspecies. They are American, European, Asian, and African. This division is based on the tropical background and the impact of geography on human physical appearance. According to skin colour, the world is divided into European white race, Asian yellow race, and African black Negro race. The skin colour depends on the tropical and geographical background, and it never stands for any sin or moral inferiority.

Frantz Fanon as a cultural critic explains the colonial relation between the European white race and African black Negro race. In this relation, colour becomes the curse of life for the Negro people. The Negroes are humiliated for their blackness. The colour of the skin is not only responsible for the cultural prejudice in the postcolonial society, but also for the dialect the indigenous people face the cultural humiliation at the presence of the colonial master.
Frantz Fanon's Black Skin, White Masks (1952, 1986) is an embodiment of the racial epitome between blackness and whiteness. Colonialism has divided the world's culture in black and white cultures, and it has brought together into one place where they assimilate with each other, influence each other, and dominate each other. Prejudice is seen for one culture by another culture. In the cultural study, one culture considers the other cultural practices as uncultured, backdated, strange, and odd practices. Such negative cultural consideration is practiced by the colonial masters who think themselves superior on the basis of their colour of skin, language, and for their ethnic origin. The white masters consider the black people as animal, beast, and very close to nature. For them, black stands for the son of the Devil or Satan, and their blackness marks the gravest crime. The whites consider Negroes as the blackest hole of the civilised society, but the blackness in reality does not symbolise any evil spirit. A man is black because he lives in the hot territories. He is black for his geographical background where the ray of the sun appears very strongly, and the place is very hot, and the blackness never symbolises the sin and devil spirit of life. Likewise, a man is white because he lives in the cold territories, and his whiteness does not symbolise any heavenliness. So it is a low act to judge the value of the people in the postcolonial study according to skin colour. Likewise, to evaluate a particular group of people according to the exercise of the dialects is not a good sign of a civilised society. Every language has its specific value, and all languages are important because all languages are the representatives of particular communities and their spirits. Every language has its own culture, and all languages should be respected equally. They are the representatives of the anthropologies, ethnicities, religions, and other ideologies of certain communities. The cultural discrimination by the whites based on colour and the exercise of language proves that the whites are racists, and to possess a superior place in society, they have created an inferior class based on colour and language. 


\section{The Problem of Colour}

The colour of skin plays a vital role in postcolonial cultural study. It is an issue of a hindrance for existence and a challenging matter to survive of the people of colour both in the colonised and colonial countries. For the colour, the Negroes and other black people have to hide from society, and they are accustomed to lead an absurd life. The white community hunts them. In the motherland, the Negroes and other blacks are ashamed of their colour, and they become a subaltern class in the presence of the white. Frantz Fanon addresses the colonised society as the Manichean society where indigenous black and outsider white communities live together. In this society, the indigenous people for blackness are oppressed by their white masters. The white race controls the society, and they possess the power of authority though they are outsiders. The white people are neither the ethinical inhabitants nor have they lived from the ancient time in the indigenous land. They have come for the financial purpose, to use the natural resources, for the slaves and indentured labours. They also brought the cultural existential dilemma for the black people with a financial crisis. For the arrival of the white culture, the indigenous people fell absurd and live like strangers in their motherland. They are subjects because they are defeated in the colonial war, and they are subjected and dominated for the lack of political consciousness, financial incapability, and nationalist spirit. There are several colonial issues for their subservient position in society. The colour of skin and the exercise of dialects are two significant issues that bring the inferiority for the Negroes and other black people. Frantz Fanon and W. E. B. Du. Bois (1868-1963) are two prominent figures in the postcolonial cultural study. They explained the psychologically wretched situation of the black people, especially in Africa. Fanon personally attached with the colour humiliation and discrimination as he belonged to the black society under the domination of the white French colonial authority in Martinique. He was the grandson of a slave, and his father belonged to the black bourgeoisie society.He noticed that three- quarters of the island's farms, business, and construction companies were occupied and controlled by a small number of the French aristocracy. They were the economic giants in Martinique. Besides the financial extortion, Frantz Fanon noticed the people of Martinique had been dominated according to the cultural background of their skin. A black feels an outsider and stranger in the motherland at the presence of the whites because of the colour of skin and the dialect. The motherland becomes the land of the stepmother. The black people live with double dimensional identities. It is not easy to find out an actual identity, and they lost in the motherland. Frantz Fanon, in Black Skin, White Masks $(1952,1986)$ has pointed out that a man of colour has two dimensions, one with his fellows and the other with the white man. A Negro feels comfortable with his clan, but he has lost that comfortable feeling in the presence of the white. The first dimension is not harmful, and it is good for coloured people. It provides him ethnic pleasure. While a black man talks with another black man, he resembles with other. A black man is the mirror of the other black man, and there is a harmony in the conversation between the people of colour. But this harmony is lost in the second dimension when a black comes to live with the white. He cannot resemble himself with the white because of the colour of his colonial master is not coloured like him; and the master possesses white uncoloured skin. The conversation of the black people is free and open as they belong to the same ethnic group, the same culture, exercise the same dialects, and overall they have the same colour of skin. No barrier of colour or language is noticed while a Negro talks with other Negro, and nobody feels superior and inferior on the basis of colour. But in the second dimension, the meeting between the white masters and the black subjects, the discrimination is explicit. For blackness, such meetings darken the spirit of the people of colour; and then they are blackened, both physically and mentally. There is a hidden border of colour that splits people in the colonised society. 
Another black cultural critic W. E. Du. Bois has explained colour trauma in his The Souls of Black Folk (1903). He has cited that a black man has a double consciousness about his identity, which Frantz Fanon later explained in his Black Skin, White Masks. A man of colour fails to recognise himself and his originality in the presence of the white. In The Souls of Black Folk Du. Bois has used the concept of "Double Conscious" for the African-American people in America, and it is explained from the white cultural background, whereas Fanon explains his "Double Dimensions" from the black cultural background. The black people in America are not the ancient ethnic people of America, and they were migrated through the slave trade and for the policy of the indentured labour. They have lived generation after generation, but they are very conscious that they do not belong to the mainstream of American society like the whites. For the skin colour and their migrated history, they are conscious about the exclusion from the mainstream of American society. This is the first consciousness of all the black people in America. At the same time, the black people are very conscious that they are black, and they have their own black culture, ideology, and norms of living which are totally different from the mainstream of American society. This consciousness is the second consciousness of the American people of colour. It is the colour of skin that stands as a borderline between the American white and black people. It is clear that they face humiliation and are pushed into the subservient position in American society, but they never deny their blackness. They use colour as a weapon to survive in the white society. They hold the black as a mark of the heavenly living. They focus on the black culture in the white society. In that regard, the Harlem Renaissance has played the most precious role to survive the black culture in the white American society. But for the Negroes and the other African people of colour, the colour of the skin has played a different role in African countries at the presence of the white culture. For them, blackness is the darkest mark of life, and they in order to be white, begin to imitate the white culture. The colour becomes a hindrance in the path of healthy living. They have to face humiliation both in the motherland and in the master land. To escape from the humiliation, they use a white mask to cover their colour. The coloured people in America use colour as their surviving material, whereas the coloured people in African countries attempt to hide their colour to survive and healthy living. Thus, the colour plays different roles for people of colour in their homeland and in their migrated land. They serve the white society, but the reward for this service is an obscenity. Young Frantz Fanon and other young black men served in the French army during the Second World War. They joined the army to save the life of their white French masters from the white enemy. They shed blood for them, they sacrificed their lives for them, and they received the gallantry awards like humiliation, obscenity, and rebuke. Fanon experienced this humiliating conduct from the French authority for them he risked his life. In war celebrated parties, the black soldiers were avoided, and they were looked as strangers, and none of the white ladies was eager to dance with the black soldiers, whereas the white ladies danced with the white war prisoners. They hated their war friends because of their colour. In the war parties in French, Fanon and other black soldiers were avoided by the French ladies. Fanon and his fellow soldiers were avoided because they were men of colour. Besides this personal experience as a soldier, Fanon had also faced colour discrimination several times. After the Second World War, Fanon enrolled himself as a medical student in medical school at the University of Lyons in Paris. As a black student, he faced colour prejudice from the white teachers and fellow students. As a black scholar in white society, this personal experience is expressed through his narration of the black scholar in the text Black Skin, White Masks. The black Negro student is always busy with books, he leads an isolated academic life, and he has no friends to spend the time. The books are the only friends and mates to pass the time. He leads a lonely life, and none of the white students is eager to make friends with people of colour. The experience which Fanon had received as a black scholar is known as intense depersonalisation. 
Fanon's intense depersonalisation resembles with Du. Bois' inaudibility, and Ralph Ellison's invisibility. In his Invisible Man (1952), Ralph Ellison portrays the life of a black man in the white society where he leads an invisible life. His invisibility is found not through his physical disappearance but through the psychological disappearance. He is ignored in society, and the white people deny his presence among them. The next important area of colour and its impact is noticed in the wage system in the colonised industrial society. Both black and white labours work together and follow the same routine of work, but the labours are paid different wages according to the colour of their skin. The white labours receive high wages, whereas the black labours receive low wages. The consciousness about colour also influenced the psychology of the colonised women for selecting their life partners. Frantz Fanon talks about two types of women in his Black Skin, White Masks, they are Negress and Mulatto; and both have a fantasy about blue eyes and white skin. The difference between these two category women is that the Negresses accept black men as their husbands, whereas the Mulattos avoid black men as their life partners. A Mulatto does not like to return to her colour origin as she possesses white blood in her vein. It was colonialism that brought racism according to the colour of skin in the Manichean society. Before European colonialism, the indigenous society never faced racism on the basis of colour, though there were other issues of racism; colonialism brought a new type of racism. The Europeans used colour as a racist barrier. They think of themselves as the saviours of the world; they are noble, civilised, and possess all the dignified qualities of life; but in actuality, they are racists. They have created an inferior class, a sub-category of the human species. The black people, the Negroes, and other colonised person belong to inferior classes; they are inferior because they are made to be inferior. They belong to the lower races, and this concept is created by the white. The whites are racists, and they have created an inferior class in the postcolonial cultural society. The whites are intellects, they have known the actual reason behind the blackness of the black people, yet they consider blackness as the dark spot of the civilised society. The Whites think Black symbolises the devil, savage, uncultured, beast, and very close to nature rather than the geographical and other biological reasons for blackness. Such dogmatic ideology of the white people is a mark of the darkness of white psychology. If the white people live in Africa generation after generation, they would also be black; the whites are whites because they are not the representatives of God, they are whites because they live in cold places. Likewise, the blacks are black because they live in hot African and Asian Continents. The consciousness about colour impacts the life of black society. The colour people consider black as the curse in their lives, and they want to deny their black identity through the denial of blackness. To be white, they renounce the jungle and the colour. The task of denial is not an easy process, and they are unable to be white because the blackness and the jungle belong to the spin of the black people. In Black Skin, White Masks, Frantz Fanon stresses that black people want to use the white mask to hide their colour identity. To cover the blackness, they imitate the white culture after denial of the black identity.

\section{The Problem of Language \& Literature}

Language and literature are the spirits of any culture. The culture is expressed through the exercises of the language and literature. Every ethnic group has its own culture, and it is represented in society through the exercise of language and literature. If the language and literature of any society are dominated or pushed into a subservient position, then automatically, society's culture moves backwards, and it struggles to survive. To abolish the culture and challenge the existence of culture in a particular community, one must first dominate the language and literature of that community. In society's postcolonial power structure, language and literature are regarded as the soft powers to abolish the colonised cultural identity. Contradictorily the capability of speaking the language of others provides the capability to communicate with the other, but it is also a concern to conceive the cultural settings 
of that recognised community. Colonialism is the tussle field where the language is shapedreshaped, formed-reformed, and decayedoriginated. According to the Eurocentric vision, colonialism is a movement, and it brings a chronology of orders and systems over the NonEuropean societies after abolishing the indigenous codes of living. Colonialism has changed the codes of conduct of the colonised people and impacts the dialects. The language and class structure of the society are interlinked. Society is divided into classes, and the different usages of language are noticed according to the class structure in society. A colonised society is divided into three major classes: colonial master, the native bourgeoisie or aristocratic society, and the poor class or proletariat. The colonial master uses the colonial language, especially French or English. They are the masters of society, and their language is the master language. They also use dialect in order to give order to their subjects. The native aristocratic society uses both the dialect and the colonial master's language, but they prefer the master language rather than the dialect. For them, the master language is a kind of mask to hide their identity. The proletariat uses the dialects at the beginning of colonialism, and they also attempt to imitate the master language. Later all the colonised subjects, including the elite class, attempt to imitate the master language. Thus the exercise of language depends on the power structure of the society.

The destiny of the dialects would face the critical position for its existence for the colonialism as the importance of the dialect has been gradually decreased. The dialect has lost its importance to the native aristocratic society and then to the remaining society. It is this society that is responsible for the decayed position of the dialect. The indigenous bourgeoisie society considers it a shameful act to speak dialects both in personal and professional lives. They are ashamed of their dialect. In the colonised society, the colonial language is the master and official language, the language of the honourable society. It is noticed that for colonialism, the colonial master has created a new class that stands between the colonial master and their colonised subjects. They are parasites of society. They are natives, but they are parasites, originated from the European colonial policy. They blindly follow the colonial masters. This class includes the native bourgeoisie-aristocratic societies and literate people. This group from the indigenous side is the primary reason for the destruction of the dialects. The bourgeoisie and aristocratic people imitate the colonial culture and language, and they profoundly exercise French and English rather than Creole, Gikuyu, and other native dialects. According to Frantz Fanon, they teach their children to take seriously French and English languages and to neglect the dialects. They rebuke and give corporal punishment to the children for speaking dialects. The children are taught to hate dialect and to love French and English. Thus a wretched platform for the dialect has been created by the indigenous bourgeoisie and aristocratic societies. When the children become grown-up members of the society, they generally prefer French, English or other colonial language rather than dialects. They have forgotten the dialect, their mother language and accepted the colonial language as their primary language. Thus the dialects are replaced from the mainstream of the society by French, English, or other European languages. The dialect is used in the proletariat society and among the poor class people. A man of high class exercises the dialect when he deals with a poor and lower class subject in order to give order. An elite person does not use the dialect for another elite person. It is used between lower people, and between elites and needy people. Later the poor and lower class people begin to imitate the colonial master's language as it symbolises the changes of the class structure of the society, and in order to belong to the superior class, the working people also begin to exercise the colonial language. Thus the dialect at first lost its value to the aristocratic society than to the remaining colonised society. The elders of the high-class families use the dialect while talking with their servants to give the order. The dialect becomes the language of the servant. Frantz Fanon in the Black Skin, White Masks criticises indigenous 
higher and middle classes for their roles to destroy the dialect. According to Fanon:

The middle class in the Antilles never speak Creole except to their servants. In school the children of the Martinique are taught to scorn dialect. One avoids Creolisms. Some families completely forbid the use of Creole, and mothers ridicule their children speaking it (Black Skin, White Masks, 1967, p. 20).

In the French-Martinique, the black children learn French both in-home and school. The elders use the songs and folklore as the teaching methods of the French for their children. Je Suis Francais are the first three French words that black children learn to read and write.

In the colonised society, language is very much crucial for economic sources. Speaking the colonial master language is a good shine of getting a job or being employed under the colonial government. It has been already told that French, English, and other European languages are the master languages in the indigenous countries. If a native speaks French, it becomes easy for him to obtain a job in the French colony, and the capability of the English also provides the chance to be employed in an English colony. The colonial master controls all system of the indigenous land. To have a swift ruling system, the masters have to contact their indigenous subjects, and in that situation, the language is the main barrier between the colonial subjects and masters. The masters do not know the dialect, and it is difficult to pass a message to their subjects. In such conditions, the colonial masters need help from such natives who are acquainted with both languages and play the role of the conveyors of their messages. Such a situation provides the opportunity for those indigenous people who are acquainted with the colonial master's language. Thus language plays a vital role in the financial changes for the indigenous people. At the same time, by using the master language, the natives are happy because this allows them to change their economic status and become a way to change their position in society. It is a benefit of the colonial master language for the natives. But such usage or situation of language has a terrible effect on the dialects. This situation is an onslaught to the dialects. At first, it affects the psychology of the children. The colonised children from their childhood are educated with their ethical stories, folklore, and traditional stories from homes and primary schools. At the primary level, they are educated with dialect. They learn their culture, tradition, and dialect in their primary teaching. The problem was waiting for them when they began their higher education. In high school and colleges, the education system is based on the colonial curriculum. When they enter colleges, the children find out that their childhood education is invalid and valueless. For the lack of language power, the indigenous students do not perform properly in their education. At first, in higher education, they face the problem regarding language. The dialects are far away from the system. Whatever they have already learnt is not treated in the higher education system. The medium of the education system is the colonial master language, and it is not easy for the indigenous scholars to perceive the subject matter of the syllabus. In his Decolonising the Mind, the Kenyan writer and theorist Ngugi Wa Thiongo narrate the plight of the Kenyan students in the British colony of Kenya. Thiongo shares his personal experience of English in Kenya. The Kenyan students are educated with Kenyan folklore, and they learn through the Gikuku. Their childhood harmony is destroyed when they enter the higher education system where English becomes the language of formal education, and there is no place for the dialect Gikuku. The system becomes more than a language, meaning English is the central part of this system.

Thiongo says that a student is humiliated and given corporal punishment if he is caught speaking Gikuku in the academy. The reading or writing capability of English is highly rewarded. The capable students are given prizes, and they enjoy high prestige. Thiongo narrates the story of a fellow student of his batch who is excellent in all subjects, but he is weak in English; for this weakness, he is failed in the final exam. His 
excellent performance on the other subjects is ignored as he fails in English.

But on the other hand, Thiongo himself is weak in the other subjects but is able to read and write English. As a result, he is qualified for the exam. In Norton Anthology (2012, p. 2739), Thiongo says:

All the papers were written in English. Nobody could pass the exam who failed the English language paper no matter how brilliantly he had done in the other subject (Norton Anthology, 2012, p. 2739).

And it has already told that the acknowledgement of the colonial language is the way to establish a reputation in the society by the natives. After the education, Ngugi Wa Thiongo works in the Alliance High School in Kenya, whereas his narrated fellow student works as a turn boy. Such an incident conveys a negative message for the dialects. Thus the value of the dialect is gradually decreased among the indigenous people. Both the indigenous family and society are responsible for the reduced condition of the dialect.

The impact of the master language is clearly visible on the indigenous society. The language becomes a soft power weapon to dominate society. The usage of language brings class discrimination among the indigenous people. The natives who know the colonial language and become the messengers of the colonial master to their fellows and think of themselves as the sub-masters. It is the power of language that has changed the social status of the indigenous representatives of the colonial authority who are well known with the master language. In Black Skin, White Masks, Frantz Fanon talks about the prejudice of the black soldiers in the French colonial army. In the Senegalese regiment, the black officers are proud as they play the role of the interpreters and conveyors of messages of their colonial master.

In the French colonial army, and particularly in the Senegalese regiments, the black officers serve first of all as interpreters. They are used to convey the master's order to their fellows, and they too enjoy a certain portion of honor (Black Skin, White Masks, 1967, p-1819).

In the postcolonial cultural study, language is one of the significant issues to stress profoundly. It is formed-reformed, shaped-reshaped, and lost and creates a new genre of language. It is noticed that most linguistic forms of dialects are lost, but at the same time, colonialism has also influenced the linguistic form of the colonial master language. The structures of languages, including dialects and colonial master language, have changed. While the natives use their master language, they include words from dialects, and they exercise a mixed language. Thus hybridism is noticed in the linguistic formation. Such a form of language is known as the pidgin language by Frantz Fanon. They add dialects with the master language. The language becomes a hybrid like culture in the postcolonial study. Pidgin is a language that includes vocabulary both from French and Creole.Thus the colonialism has created a new form of master language and literature. Colonialism devastatingly influenced world literature. It has produced several branches of literature taking ingredients from the indigenous and colonial literature. The indigenous writers use the colonial language as the medium of writings, and they take subjects from the indigenous culture. Thus the spirit of the colonised society is reflected through the colonial master languages. For example, the Indian English language and literature must be mentioned. The African English literature and African English language are created with colonialism. For colonialism, the European languages are divided into two categories. The first one is the European languages used by the Europeans. The second one is the indigenous people's hybrid or mixed European languages by adding dialects with the colonial master language. Indian English language and literature, African English literature and language, and pidgin are the NonEuropean languages.

Frantz Fanon has made a serious charge to the role of the family for the humiliated position of 
the colonised people based on the colour of skin and dialect. He criticises the colonised family philosophy, psychology, and ideology for their subservient position. The colonial masters indeed think of them as the sub-part of the society, but the colonised people are equally responsible for it. A black child from childhood learns the black is the mark of evil, the colour of the skin indicates the second class position in society, and the dialect is not a valuable language for the people. A black from childhood notices that their elders are subjects to the white, their elders are beaten in the streets; and the white stands for the superior position of the society. This is the condition of the black families for their children.

On the other hand, the white families teach the white children so that the children think of themselves as the saviour of the world. They are the heroes who would save the world from every danger and the black people as their subject. Frantz Fanon criticises this dogmatic philosophy both of white and black families. A normal child becomes a normal member of society, but the story is different for a normal black child. It is applicable to white children. But for black children, the situation never remains normal. It becomes abnormal when they become the grown-up. For the black children, both family and society set different ideologies of living.

The consciousness, value, and importance of the colour and dialect are survived among the colonised intellectuals. During and after European colonialism, the indigenous intellects struggle to survive and attempt to bring back the earlier prestige of the dialect and establish equality among all people of colour. The critics like Frantz Fanon criticise the colonial policies for the subservient position of the black culture based on dialect and colour. They also think to abolish the English or other colonial department from the indigenous lands by replacing the indigenous dialect and literature in the education system. 'On the Abolition of the English Department' is a radical proposal by the African intellects to reform their education system, the system which the colonial education system has influenced. In this radical proposal,
Ngugi Wa Thiongo, Taban Lo Liyong, and Henry Owuor-Anyumba debate about abolishing the English department from the African education system. They prefer that their education system must be focused on Africa, its culture, its folklore, in short, Africanism; this debate is vital regarding the restoration of Africanism after the destruction of European colonialism. They think to replace the English Department with the Department of African Literature and Language.

\section{References}

Althusser, Louis (2014). On The Reproduction of Capitalism: Ideology and Ideological State Apparatuses. Verso.

Arnold, Methew (2015). Culture and Anarchy, and Other Selected Prose. Penguin Classic

Bois, W.E.B.Du \& Alexander Shawn Leigh (2018). The Souls of Black Folk: Essays and Sketches. University of Massachusetts Press.

Buchanan, Ian (2009). Oxford Dictionary of Critical Theory. First Edition. Oxford University Press. England.

Carl Linnaeus. New Scientist.

www.newscientist.com

Carolus Linnaeus Biography, Facts and Pictures. Famous Scientists. www.famousscientists.org

Cherki, Alice (2006). Frantz Fanon: A Portait. Ithaca and London. Cornell University Press.

Eligon, John; Arango, Tim; Dewan, Shaila; BogelBurroughes, Nicholas (2021, 20 April). Derek Chauvin Verdict Brings a Rare Rebuke of Police Misconduct. The New York Times. https://www.nytimes.com/2021/04/20/us/geor ge-floyd-chauvin-verdict.html

Fanon, Frantz (1967). Black Skin, White Masks. Translated by Charles Lam Markmann, Grove, ---. A Dying Colonialism. Grove Press.

Fanon, Frantz (1967). The Wretched of the

Earth. Translated by Constance Farrington, Penguin

Gilroy, Paul (1993). The Black Atlantic:

Modernity and Double Consciousness. Harvard University Press. 
Gramsci, Antonio (1999). Selections from the Prison Notebooks. The Electric Book Company Ltd.

Greenblatt, Stephen (ed).(2012) .The Norton Anthology of English Literature. W. W. Norton \& Company, Inc.

Grossberg, Lawrence (2010). Cultural Studies in the Future Tense. Duke University Press.

Leitch, Vincent B.(ed.)( 2010). The Norton Anthology of Theory and Criticism. W. W. Norton \& Company, Inc.

Macey, David (2001). Frantz Fanon: A Biography. Picador USA

Pulla, Venkat, Bhattacharyya Rituparna, \& Bhatt Sanjai (2020). Discrimination, Challenge, and Response: People of North East India. London: Palgrave Macmillan, DOI:10.1007/978-3-03046251-2
Race: Definition, Ideologies, Constructions, \& Facts. Britannica. www.britannica.com

Reinhard, Wolfgang. (2011). A Short History of Colonialism. Manchester Press

Thiong'o. Ngugi.Wa. (1986). Decolonising the Mind: The Politics of Language in African Literature. James Currey.

Williams, Raymond. (1960). Culture and Society:1780-1950. Columbia University Press

Zahar, Renate. (1974). Frantz Fanon:

Colonialism and alienation; concerning Frantz Fanon's Political Theory. Monthly Review Press.

\section{Conflict of Interest}

The author has no conflict of interest

\section{Acknowledgements}

The author is highly grateful to the anonymous reviewers and the copyeditors for helping me improve the manuscript. 